Acta vet. scand. $1976,17,379 \longrightarrow 394$.

From the Equine Hospital, Solvalla, Stockholm-Bromma and the Research Department, Pharmacia AB, Uppsala, Sweden.

\title{
INTRA-ARTICULAR TREATMENT OF ARTHRITIS IN RACE-HORSES WITH SODIUM HYALURONATE
}

By

Ake Asheim and Gert Lindblad

\begin{abstract}
ÅSHEIM, ̊̊KE and GERT LINDBLAD: Intra-articular treatment of arthritis in race-horses with sodium hyaluronate. Acta vet. scand. $1976,17,379-394$. - Forty-five race-horses with arthritis of non-infectious type in 54 joints were treated with sodium hyaluronate intra-articularly. All joints had previously been treated without lasting success by conventional methods, such as firing, blistering or intraarticular injection of cortisone. In most cases only 1 injection of $2 \mathrm{ml}$ $(20 \mathrm{mg})$ sodium hyaluronate was needed. To avoid subjective evaluation, the effects of the treatment were based on the joint's capacity of withstanding extreme stress, which means that the horse should be able to train and race again. The treatment was concentrated on the carpal and fetlock joints. Of the 54 joints treated only 5 did not show any improvement. Thirty-eight were free from lameness - 32 of them returned to the race-track. The observation period was at least 1 year. No side effects were observed.
\end{abstract}

arthritis; corticosteroids; sodium hyaluronate; race-horses.

Arthritis is a common disease amongst race-horses. It is generally treated by intra-articular injection of corticosteroids or with counterinflammation therapy, such as firing or blistering.

Corticosteroids often give rapid improvement. However, side effects are observed when the treatment is repeated, which may aggravate the diseased joints (Farquharson 1966, Salter et al. 1967, O'Connor 1968, Meagher 1970). Since treatment with corticosteroids has limitations, there is still an urgent need for an agent for intra-articular treatment of arthritis in race-horses which could be combined with or replace corticosteroid and counterinflammation therapy. Rydell et al. (1970) arrived at the opinion that injection of sodium hyaluronate ( $\mathrm{SH}$ ) combined with cortisone resulted in a better, more prolonged effect on 
arthritis than cortisone alone. The article providing no obvious reason for the better effects of the combination, the question was raised as to the effects of $\mathrm{SH}$ alone. To test this, $\mathrm{SH}$ was injected in joints in which conventional treatment previously had no lasting effect.

\section{MATERIAL AND METHODS}

\section{Sodium hyaluronate}

Hyaluronic acid is a heteropolysaccharide - a polyanionic glucosamino glucan formerly designated mucopolysaccharide. Its repeating unit is a disaccharide of glucuronic acid and $\mathrm{N}$-acetylglucosamine linked by a $1-3$ glucosidic bond. These disaccharide units are linked together by $1-4$ glucosidic bonds to form a long unbranched chain. The sodium salt of hyaluronic acid ( $\mathrm{SH}$ ) is shown in Fig. 1.

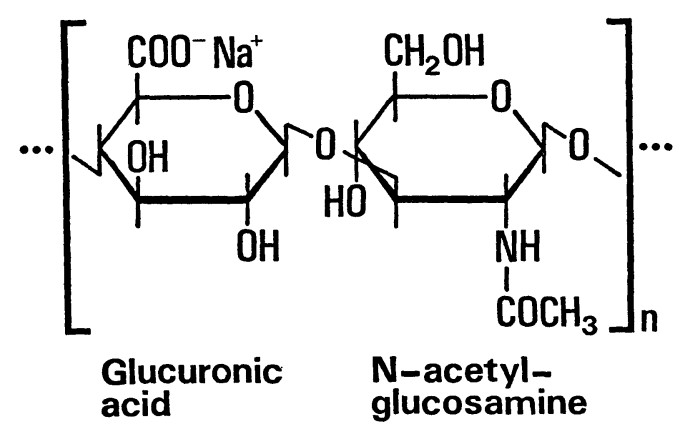

Figure 1. Sodium salt of hyaluronic acid.

$\mathrm{SH}^{\star}$ from both human and avian sources was used in this investigation. One $\mathrm{ml}$ of the solution contained $10 \mathrm{mg}$. Two $\mathrm{ml}$ of $\mathrm{SH}$ was injected except in some cases where an initial dose of $4 \mathrm{ml}$ was used (case Nos. 1 and 2 in Table 1; case Nos. 13 and 17 in Table 2 a and No. 32 in Table 2 b). A volume of synovia was removed that was equal to the amount of SH injected, except in cases with excessive synovia when more was removed. The intra-anticular injections were performed under aseptic conditions. With nervous horses (in order to avoid extra traumata) a local anaesthesia was applied subcutaneously to the site of the injection. After the treatment the horses were exercised very

* Kindly supplied by Balazs, USA. 
gently during the following 2-4 days and thereafter returned to their normal training programmes.

The present investigations were carried out in 1970-1974 with an observation period after treatment of at least 1 year. SH injections were studied in 28 Thoroughbreds and 17 Standardbreds (trotters). In these animals 54 joints in all were injected, 38 of which were fetlock joints, 14 were carpal joints and 2 coffin joints (see Tables 1-4). The investigation was conducted on non-infected joints that had previously been treated without lasting success by conventional methods, such as firing, blistering and/or intra-articular injection of cortisone. Only joints where the lameness was washed out by intra-articular anaesthesia were treated.

\section{Classification of arthritis}

As the nomenclature and classification of arthritis are still under discussion we have in this study set out the clinical observations for each joint in table form. The observations comprise:

1. Initial lameness, flexion reaction and lameness after intraarticular anaesthesia

2. Capsule thickening

3. Increase in synovia

4. X-ray examination

1. The degree of lameness and flexion reaction was assessed on a scale from 0 to 5 , where 0 represents no lameness and 5 is threelegged. Generally only 1 joint in each horse was treated. Where 2 joints of the horse were injected, this without exception involved the corresponding joints of each leg. In those cases where there was a double lameness, the degree of lameness given in Tables 1-4 for each joint was assessed after the lameness in the other joint had been eliminated by anaesthesia.

2. The degree of capsule thickening was assessed from the results of palpation and X-ray observations. The grading is from 0 to 3 , where 0 is normal and 3 indicates major enlargement.

3. The increase in the synovia was determined by palpation. The scale is from 0 to 3 , where 0 is normal and 3 indicates an excessive increase in synovia.

4. Radiologically confirmed changes were graded from 0 to 3 . The assessment is based only on the degree of intra- and periarticular osseous deposits.

$0=$ No demonstrable changes

$1=$ Very slight osteophytosis

$2=$ Moderate

$3=$ Marked

The radiological examination was conducted on all horses except case No. 22 in Table 2 a. 


\section{Evaluation of the effects}

The assessment was based on the horse's racing capacity after the treatment with $\mathrm{SH}$ and on whether any reaction developed in the joint after racing. In order to qualify for starting, the horse must not show any lameness. This is carefully checked before the race by a state employed veterinary surgeon. As it is illegal in Sweden to administer any form of drug to horses during the 4 (in certain cases 14) days preceding a race, the possibility of giving an agent that would hide the lameness is precluded. The results of the treatment are graded +++ to 0 , where

$$
\begin{aligned}
+++= & \begin{array}{l}
\text { Excellent. No lameness or flexion reaction before or after } \\
\text { the race. }
\end{array} \\
++= & \text { Good. No lameness before or after the race but a slight } \\
& \text { flexion reaction after race. } \\
+\quad & \text { Fair. No primary lameness. Able to train and race but slight } \\
& \text { lameness and a measurable flexion reaction after the race. } \\
= & \text { No lasting improvement. Lameness and a flexion reaction } \\
& \text { were both evident or returned when training increased. } \\
& \text { The horse was unable to race despite repeated injections. } \\
= & \text { Brackets indicate that the result was not tested on the race- } \\
& \text { course, owing for instance to the incurrence of some other } \\
& \text { injury and/or to the horse's being sold as a riding horse. } \\
& \text { The results presented are based on the clinical symptoms } \\
& \text { after treatment with SH and also on the rider's assessment } \\
& \text { of how the treated joint stood up to the exercise. }
\end{aligned}
$$

\section{RESULTS}

Following injection of SH a diffuse swelling of the joint was observed in a few cases. The swelling disappeared after 1 to 4 days. Repeated injections of SH did not aggravate this swelling.

After an injection of $\mathrm{SH}$, the lameness was reduced or disappeared completely within a few hours in some cases, in other cases within a few days. In some animals the lameness did not recede until the injection was repeated. If the primary lameness remained, the injections were repeated at weekly intervals if possible.

In joints with marked osteophytosis more often than in other kinds of arthritis the flexion reaction returned after training and/or racing. An injection of $\mathrm{SH}$ again resulted in an improvement of the joint in most of these cases.

Several of the horses treated with SH were untrained as they had previously undergone conventional treatment followed by an extensive period of rest. In these cases the training was successively increased and the horses qualified to start in a race some 
months after the injection. For horses in full condition, the treatment was not unfavourably influenced by allowing them to train or race already a week after the injection.

\section{Carpal joint}

Fourteen carpal joints were treated, 8 of which were in Thoroughbreds (Table $1 \mathrm{a}$ ) and 6 in Standardbreds (Table $1 \mathrm{~b}$ ). Of these 14 joints, 13 were intercarpal and 1 a radiocarpal joint (case No. 1). A comparison of the clinical findings in the Thoroughbreds and the Standardbreds revealed that the changes as demonstrated by radiology were more pronounced in the Thoroughbreds. All Thoroughbreds showed a flexion reaction in the carpal joint, while 2 Standardbreds showed no similar reaction. The lameness could only be localized by articular anaesthesia.

\section{Thoroughbreds}

In 3 joints, only 1 injection was necessary, whereas it had to be repeated $1-5$ times in the others. Five out of 7 intercarpal joints were graded +++ after the injection of $\mathrm{SH}$, and it is noteworthy that they had not responded favourably to previous corticosteroid treatment followed by rest. According to the X-ray examination 3 of 7 intercarpal joints had thick osseous deposits. These 3 horses showed a slight stiffness after the race but a few days later seemed completely normal again. This may imply that the stiffness was mainly due to a mechanical influence of the osseous deposits on the surrounding soft tissue.

\section{Standardbreds}

In 4 joints, only 1 injection was necessary, whereas in 2 others it had to be repeated. Three intercarpal joints were assessed +++ . Case No. 11 showed no lameness after the injection and during training but later fractured its third phalanx of the left hindleg; is now troublefree and employed as a riding horse. Case No. 10 showed no lameness when inspected a week after the injection but was killed in an accident later. Case No. 9 showed no lasting improvement. This horse had received 3 corticosteroid injections in the intercarpal joint prior to injection of SH. 


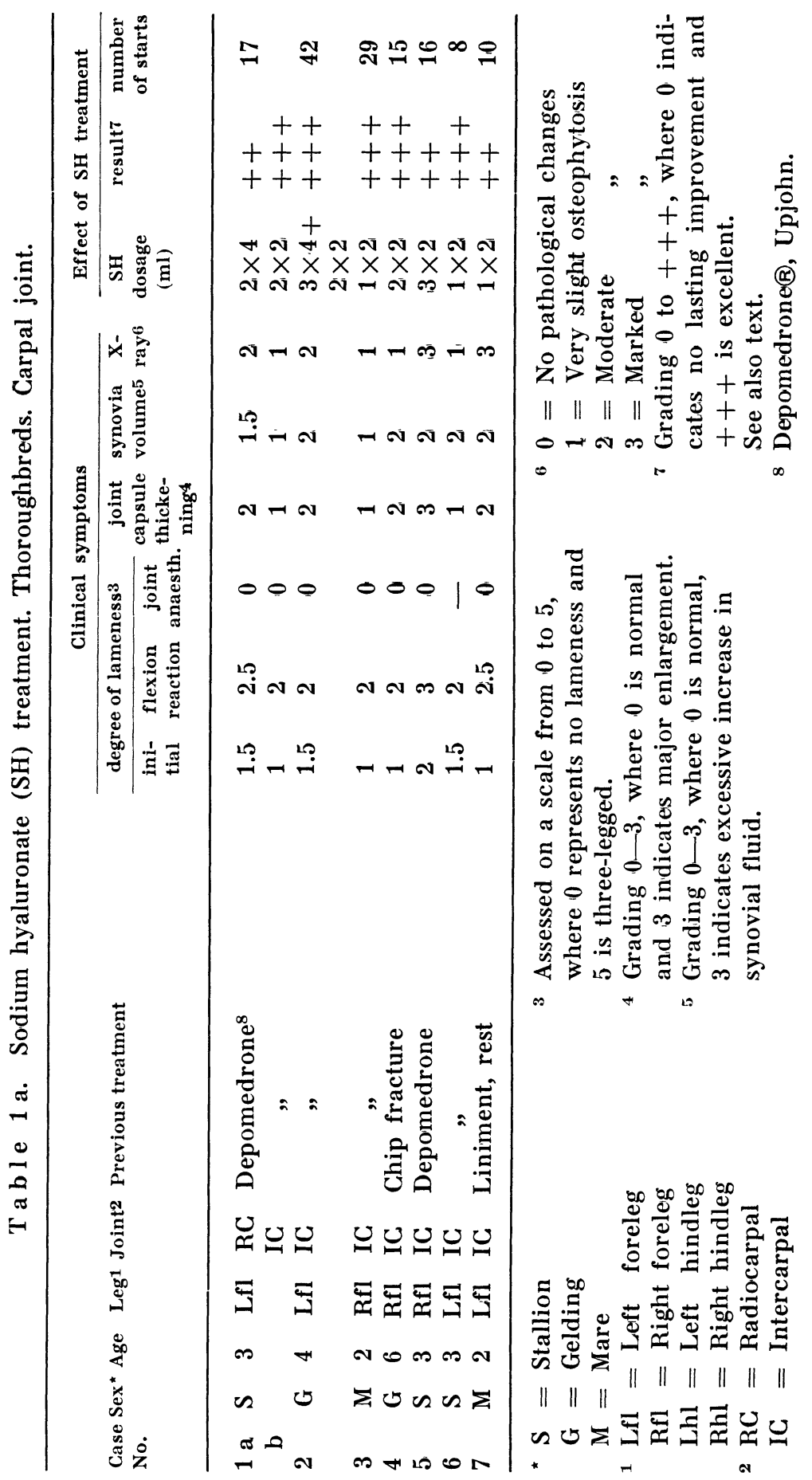




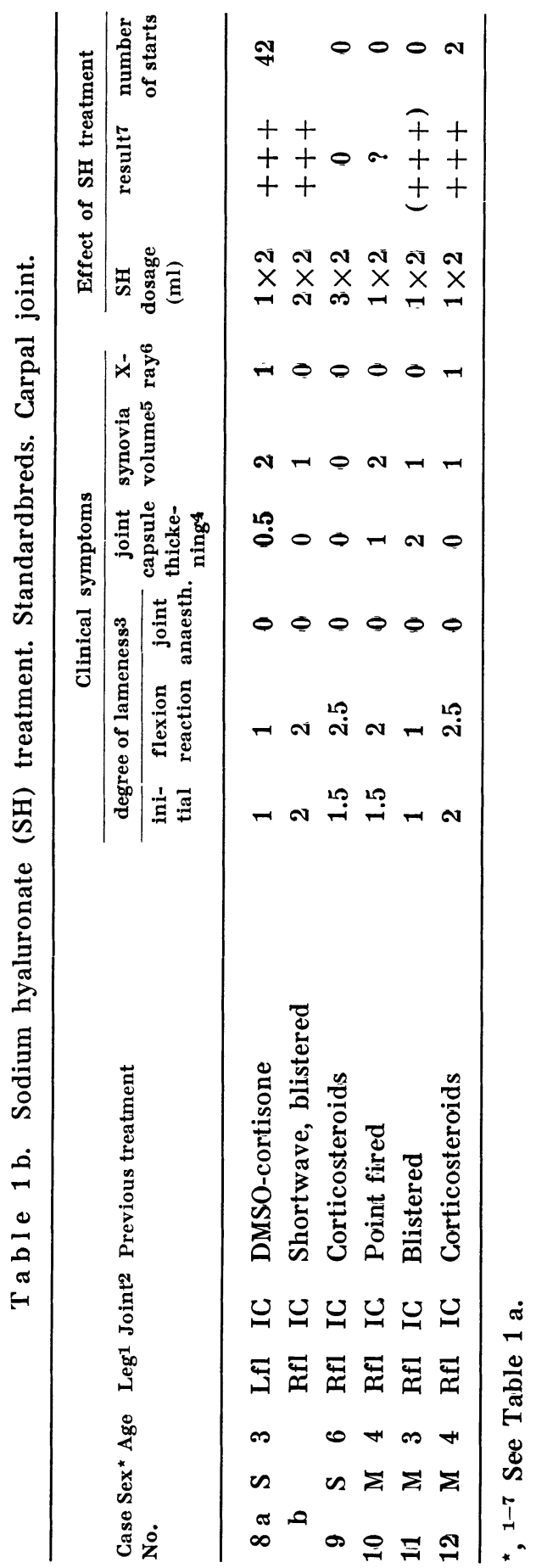




\section{Fetlock joint}

\section{Thoroughbreds}

Twenty-four fetlock joints were treated in 19 Thoroughbreds (Table $2 \mathrm{a}$ ), all of them in the forelegs except in case No. 29. Of these 24 joints, 12 were assessed as,+++ 4 as,++ 2 as,+ 3 as 0 , and 3 cases where the horse was never able to race for reasons other than arthritis. The cases where the treatment did not give a satisfactory result will be described in more detail so that the indications and limitations of SH may be better defined.

Result +++ tion.

Eleven of the $12+++$ and all $3(+++)$ received only 1 injec-

Result ++

Case No. 19 is the only 2-year-old in the fetlock-joint material. Hard training resulted in a reaction in the epiphyseal-metaphyseal region proximally to the carpal joint and proximally and distally to the fetlock joint. Blistering was repeated a number of times without effect. An X-ray of the left front fetlock joint revealed slight thickening of the capsule and a small piece of bone the size of a grain of wheat located intra-articularly proximally-dorsally to the first phalanx in the fetlock joint. After injection of $\mathrm{SH}$, the horse was able to race 5 times, but the joint then again began to react. The injection was repeated and the lameness and flexion reaction disappeared. As an inflammation later developed in the superficial digital flexor tendon of the same leg, the horse was sold as a riding horse and, according to the present owner, is still free of symptoms.

Case No. 29 was lame $1^{\circ}$ and showed a flexion reaction $3^{\circ}$ in the left hind fetlock joint. The capsule and the supporting tissue around the joint had been swollen. Point firing and adequate rest had not given any appreciable improvement. An injection of $\mathrm{SH}$ eliminated the lameness. The horse was trained and raced, but under extreme stress the joint showed a flexion reaction. The injections of $\mathrm{SH}$ were repeated twice after which the horse again improved and was able to race. A comminuted fracture of the left hind lateral sesamoid bone occurred later during a race.

Case No. 13 had developed severe osteoarthritis with very restricted bending of the fetlock joint. Repeated blisterings had no effect. After injection of SH the lameness was no longer evident. After the race, however, the joint was tender for some days. After another race, the horse was sold as a riding horse.

Case No. 17 also had severe osteoarthritis in both front fetlock joints. Treatment with blistering and antiphlogistics had little effect. The lameness disappeared after an injection of $\mathrm{SH}$, but following in- 


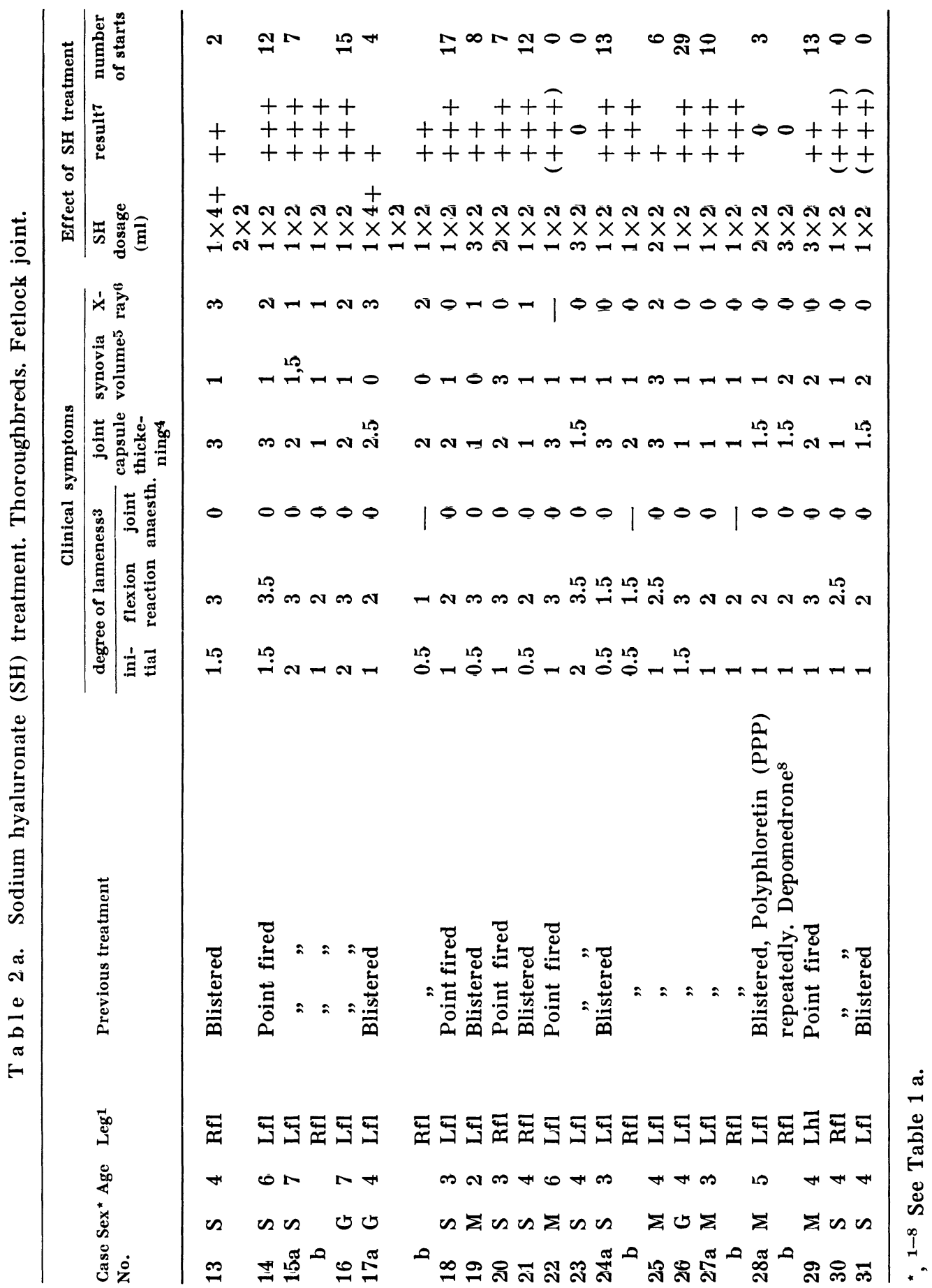


creased training the left joint again showed a flexion reaction. After careful management the horse raced 4 times. The treatment with $\mathrm{SH}$ was evaluated as follows: right joint ++ , left joint + .

Result +

Case No. 25 had been trained as a 2-year-old beyond its skeletal tolerance with subsequent reactions in the growth zones and joints. Osteoarthritis appeared in the front left fetlock joint. Lameness remained despite blistering and rest. Flexibility was clearly reduced. The same tendency as with previous osteoarthritis cases: the lameness disappeared after the $\mathrm{SH}$ injection but returned partially after increased training and racing.

Result 0

Case No. 28 raced frequently as a 2- and 3-year-old with subsequent reaction in the fetlock joints on both forelegs. Blistering and rest had no effect. Repeated injections of polyphloretinphosphate (PPP, Leo) were given in each joint. The lameness diminished after each injection but returned on exertion. Injection of Depomedrone $\mathbb{R}$ followed by repeated injections of $\mathrm{SH}$ gave no lasting improvement. By careful management the horse was able to race 3 times. It is now being used for riding but becomes lame on exertion.

Case No. 23 was the only Thoroughbred of 16 which after injection could be detected. This horse was also part of a group in which still showed a reaction after point firing and rest. Following the first injection of $\mathrm{SH}$, lameness disappeared after 2 days. No flexion reaction could be detected. This horse was also part of a group in which the synovial fluid was investigated before and a week after treatment. After the last puncture there was an inflammation of the joint, presumably a synovitis. The synovitis did not respond to repeated injections of SH. Bacteriological examination proved negative. Finally even injections of Depomedrone $($ ) were gvien without effect. This horse is now used for riding and is able to manage light exercise.

\section{Standardbreds}

Twelve fetlock joints in 10 Standandbreds were treated (Table $2 \mathrm{~b}$ ). One of them (No. 36) could not start, owing to a damaged suspensory ligament on the other foreleg. The results of the other 11 fetlock joints were $9+++, 1++$, and 1 without any persisting effect.

Result +++

Seven of the $9+++$ received only 1 injection.

Result ++

Case No. 38 is an 11-year-old trotter with persistent lameness in the left foreleg despite point firing and repeated blistering. After in- 


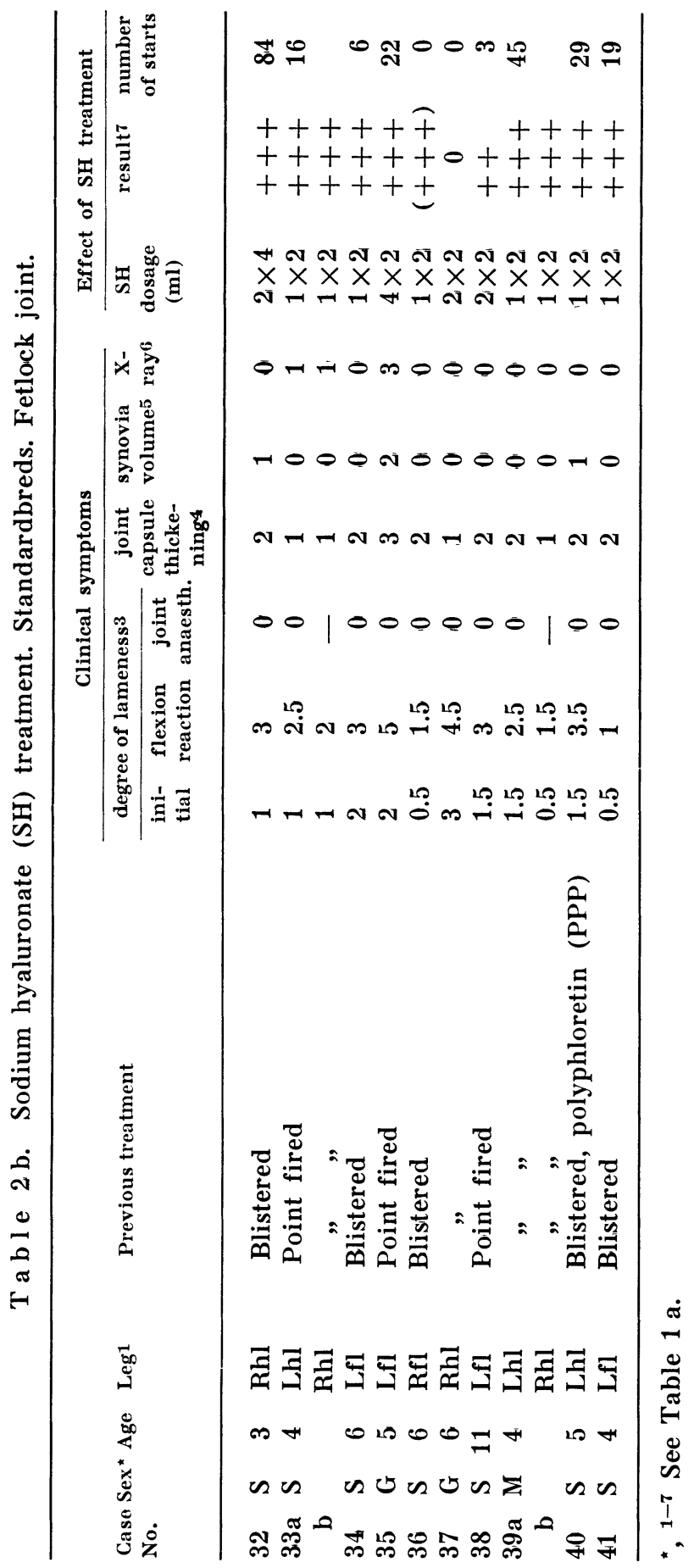


jection of $\mathrm{SH}$, the lameness receded, but after racing and hard training the joint showed a slight flexion reaction for some days after. When after 3 races an inflammation occurred in a suspensory ligament on a hindleg, training was discontinued.

Result 0

Case No. 37 had a severe lameness reaction in the joint without marked inflammatory symptoms such as heat, increased synovial volume or enlargement of the capsule. Following injection of $\mathrm{SH}$ the lameness disappeared but as soon as the training was increased the reaction reappeared. Repeated injections of $\mathrm{SH}$ caused no improvement.

\section{Coffin joint}

The coffin joints of 2 Standardbreds trotters were treated (Table 3 ). In each case the coronary band had been point fired twice without effect. The lameness reaction before $\mathrm{SH}$ treatment was in both cases considenable, $-3^{\circ}$, but was eliminated by intra-articular anaesthesia. In case No. 43 the injection of SH had to be repeated. This horse has subsequently raced 34 times without any detectable reaction in the coffin joint. Case No. 42 has not shown any reaction in the coffin joint, following the injection of SH. The effect has not been tested in a race as the horse received a blow on the leg, resulting in a severe local periostitis distally-medially to the first phalanx. Neurectomy of the medial volar nerve was then performed and the horse is now in full training.

\section{Fractured fetlock joint}

Two Thoroughbreds with fractured cannon bones (Mc III) in which the line of fracture extended to the surface of the fetlock joint, were treated (Table 4). In case No. 44 the fracture was plastered. After convalescence there were no detectable changes in the X-rays. The horse was not lame, but when training began, lameness recurred. After injection of $\mathrm{SH}$, the horse was able to race 3 times without any reaction in the joint. During the fourth race the horse fell and died. A post-mortem examination revealed that death was due to an acute infection of the respiratory tract. Inspection of the fetlock joint showed a sagittal groove in the cartilage at the site of the fracture. In addition, in the lateral part of the fetlock joint there was an erosion of the metacarpal cartilage of about $1 \times 1.5 \mathrm{~cm}$. The cartilage of the joint was otherwise normal. 


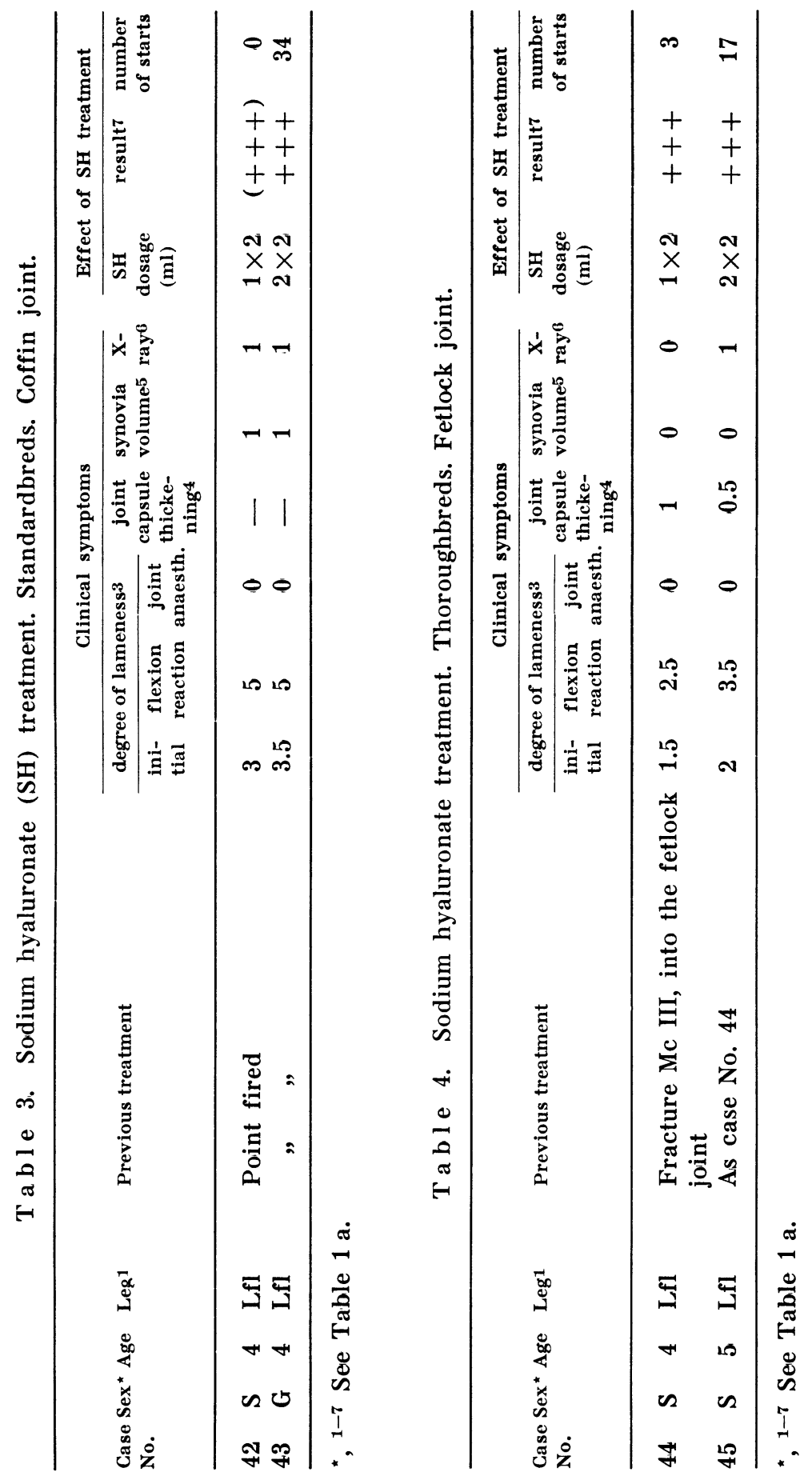


In case No. 45 the fracture was set with screws. X-ray examinations revealed a slight osteophytosis. After about 4 months' training an inflammation developed in the joint. Following injection of $\mathrm{SH}$ the lameness reaction disappeared. After the third race, a slight flexion reaction was apparent and a further $\mathrm{SH}$ injection was given. The horse has since been able to race without showing any signs of a reaction in the joint.

\section{Side effects}

From a clinical point of view no noticeable adverse reactions have been observed during 1 to several years after the SH treatment.

\section{DISCUSSION}

In the present investigation the joints selected for treatment with SH had previously been treated by conventional methods, such as blistering, firing or cortisone without lasting success. The essential aim of the investigation was to establish whether SH is effective where other methods have failed.

To avoid as far as possible a subjective evaluation, the effects of the SH treatment were based on the joint's capacity of withstanding subsequent extreme stress as the sole criterion. Thus a definite evaluation was made only in those cases where the horse was able to train and race again afterwards. The competing horses were inspected by the course veterinary surgeon, which provides a guarantee that they were not lame before the race.

The treatment with $\mathrm{SH}$ was in the first place concentrated on those joints that are exposed to the most severe strain, viz., the fetlock and carpal joints and to some extent the coffin joint.

The results reveal that treatment with SH frequently produces very good effects. Treatment of the carpal joints has previously mainly involved injection of a corticosteroid, ofiten with repeated injections. The only carpal joint (case No. 9) where SH did not give any lasting effect had previously been treated 3 times with cortisone. Since it has been established that repeated cortisone injections may lead to erosion of the cartilage, it is plausible that the changes were so extensive that SH could not exert a lasting effect.

Treatment of fetlock joints has previously consisted of point firing or blistering except in 1 case (No. 28) where injections of 
polyphloretinphosphate and Depomedrone ${ }^{\circledR}$ were given. The prognosis for most of these horses before treatment with SH was deemed unfavourable. It is remarkable, therefore, that in most cases 1 injection of $2 \mathrm{ml}$ was sufficient to cure the lameness. In most of the cases where it was necessary to repeat the injection, there were pronounced osteophytic outgrowths. The recurrence of lameness may be due to mechanical irritation of surrounding tissue rather than a relapse of the original cause of the lameness.

The question may be raised as to why a lasting effect is frequently obtained after a single injection of SH. The earlier assumption that lameness in racing horses is caused mainly by changes in the joint cartilage may no longer be tenable. Nilsson (1973) demonstrated that extensive degeneration and erosion of the joint cartilage may be present without apparent lameness. The cause may instead be attributed to synovitis. This implies that SH must also have some effect on the synovial tissue and the synthesis of normal hyaluronate and thus counteract the pathological process. Presumably the SH acts directly on the surfaces within the joint, - not only through its viscoelastic properties but also by a normalization of the hyaluronate synthesis and hence the properties of the synovial membrane and fluid which may be the explanation of the persisting effect.

Injection of SH has also shown good effect in 2 cases where a bone fracture extends to the joint. It is well known that after the usual convalescence this type of injury may lead to a recurrence of the limp as soon as the extremity is exerted. In these cases it is assumed that the recurrence of the limp is due to faulty healing of the joint cartilage and thus SH seems to have a favourable effect on this process.

\section{ACKNOWLEDGMENT}

We are deeply indebted to Prof. Endre Balazs, Columbia University, New York for the supply of sodium hyaluronate and valuable discussion in planning the trial protocol. We would add our sincere gratitude to ass. prof. Nils Rydell, Södersjukhuset, Stockholm for his part in initiating the trial. 


\section{REFERENCES}

Farquharson, W. B.: Lameness Symposium. Proc. AAEP 1966, $329-$ 343.

Meagher, D. M.: The effects of intra-articular corticosteroids and continued training on carpal chip fractures of horses. Proc. AAEP 1970, 405-420.

Nilsson, G.: De distala lederna och falangerna hos den varmblodiga travaren. (The distal joints and phalanges of the Standardbred trotter). Thesis, Stockholm 1973.

O'Connor, J. T.: The untoward effects of the corticosteroids in equine practice. J. Amer. vet. med. Ass. 1968, 153, 1614-1617.

Rydell, N. W., J. Butler \& E. A. Balazs: Hyaluronic acid in synovial fluid. VI. Effect of intra-articular injection of hyaluronic acid on the clinical symptoms of arthritis in track horses. Acta vet. scand. 1970, 11, $139-155$.

Salter, R. B., A. Gross \& J. H. Hall: Hydrocortisone arthropathy. An experimental investigation. Canad. med. Ass. J. 1967, 97, $374-377$.

\section{SAMMANFATTNING}

Intraartikulär behandling med Na-hyaluronat av artrit hos tävlingshästar.

Artrit är ett vanligt lidande hos tävlingshästen. Behandlingen består vanligen av intraartikulär injektion av kortikosteroid eller av blistring och/eller bränning.

I föreliggande arbete redovisas resultaten av behandling med Nahyaluronat $(\mathrm{SH})$, som är en normal beståndsdel i synovialvätskan. Femtiofyra leder (38 kot-, 14 karpal- och 2 hovleder) hos fyrtiofem tävlingshästar har behandlats med $\mathrm{SH}$ intraartikulärt. I de flesta fall har en injektion med $2 \mathrm{ml}(20 \mathrm{mg} \mathrm{SH})$ varit tillräckligt. I samtliga fall hade leden tidigare behandlats enligt någon konventionell metod (blistring, bränning, kortison) utan bestående effekt. Bedömningen av effekten har baserats på ledens förmåga att uthärda extrem belastning, nämligen att hästen skulle kunna träna och tävla utan att lidandet recidiverar. Uppföljningstiden har varit minst ett år. Av de behandlade 54 lederna blev 38 så färbättrade att hältan försvann och inte återkom trots ansträngning. Elva st blev klart förbättrade, men hältreaktion kunde uppstå efter tävling. Dessa hästar har dock kunnat träna och tävla. Fem st leder visade ingen påvisbar förbättring. Även i fall med röntgenologiskt påvisbara osteofytära pålagringar har ett bestående kliniskt tillfrisknande erhållits. Inga påvisbara kliniska biverkningar har observerats.

(Received August 30, 1976).

Reprints may be requested from: Gert Lindblad, Research Department, Pharmacia AB, Box 181, S-75.1 04 Uppsala, Sweden. 



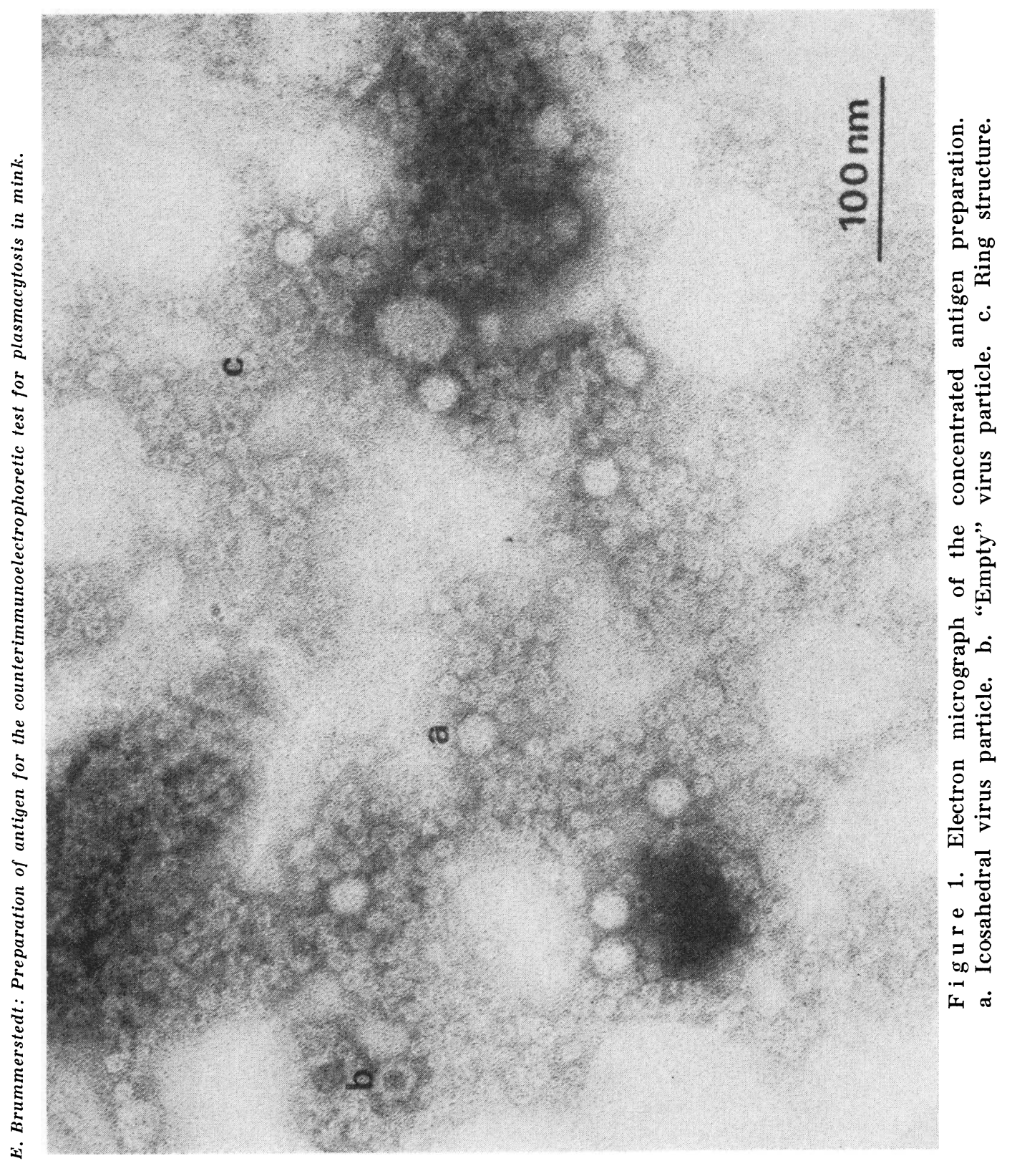

